\title{
Temperature Distributions in Single Cell of Polymer Electrolyte Fuel Cell Simulated by an 1D Multi-plate Heat-Transfer Model and a 3D Numerical Simulation Model
}

\author{
Akira Nishimura ${ }^{1}$, Masashi Baba ${ }^{1}$, Kotaro Osada ${ }^{1}$, Takenori Fukuoka ${ }^{1}$, Masafumi Hirota ${ }^{1}$ and Eric $\mathrm{Hu}^{2}$ \\ 1. Division of Mechanical Engineering, Graduate School of Engineering, Mie University, Tsu-city, Mie 514-8507, Japan \\ 2. School of Mechanical Engineering, The University of Adelaide, Adelaide, SA 5005, Australia
}

Received: April 30, 2015 / Accepted: June 01, 2015 / Published: August 31, 2015.

\begin{abstract}
The purpose of this study is to verify an 1D multi-plate heat-transfer model estimating the temperature distribution on the interface between polymer electrolyte membrane and catalyst layer at cathode in single cell of polymer electrolyte fuel cell, which is named as reaction surface in this study, with a 3D numerical simulation model solving many governing equations on the coupling phenomena in the cell. The results from both models/simulations agreed well. The effects of initial operation temperature, flow rate, and relative humidity of supply gas on temperature distribution on the reaction surface were also investigated. It was found in both $1 \mathrm{D}$ and $3 \mathrm{D}$ simulations that, the temperature rise (i.e., $T_{\text {react }}-T_{\text {ini }}$ ) of the reaction surface from initial operation temperature at $70{ }^{\circ} \mathrm{C}$ was higher than that at $80^{\circ} \mathrm{C}$ irrespective of flow rate of supply gas. The effect of relative humidity of supply gas on $T_{\text {react }}-T_{\text {ini }}$ near the inlet of the cell was small. Compared to the previous studies conducted under the similar operation conditions, the $T_{\text {react }}-T_{\text {ini }}$ calculated by 1D multi-plate heat-transfer model in this study as well as numerical simulation using 3D model was reasonable.
\end{abstract}

Key words: Polymer electrolyte fuel cell, 1D multi-plate heat-transfer model, 3D numerical simulation model, temperature distribution.

\section{Introduction}

PEFC (polymer electrolyte fuel cell) is promising clean power-generation technology. However, there are some barriers preventing PEFC from being used widely among industries and homes worldwide. Some of such barriers are the reduction in power-generation performance and life span caused by the uneven distributions of mass concentration and temperature inside cell of PEFC. Local temperature rise and gas diffusion blocked by condensed water are reasons for the uneven distribution [1-4].

This study investigates temperature distribution inside

Corresponding author: Akira Nishimura, associate professor, research fields: heat transfer, fuel cell, photocatalyst and smart city. E-mail: nisimura@mach.mie-u.ac.jp. single cell of PEFC. Uneven temperature distribution causes degradations of PEM (polymer electrolyte membrane) and catalyst layer. Local temperature rise would cause thermal decomposition of PEM. PEM could be broken by thermal stress caused by the uneven temperature distribution $[3,5,6]$. Temperature distribution influences the phase change of water. Water's behavior influences the performance of the PEM and gas flows in GDL (gas diffusion layer) and catalyst layer. Temperature also affects the performance of PEM and catalyst layer. Hence, it is important to clarify the temperature distribution in single cell of PEFC in order to improve the power-generation performance and realize the long life span.

Refs. [7, 8] reported an experimental study on current density and temperature distributions in a cell 
of PEFC under several operation conditions. Refs. [7, 8] measured temperature distributions by 10 very thin thermocouples located between GDL and catalyst layer at cathode. The temperature distribution along gas channel of separator was discussed in these Refs. [7, 8]. However, the width of insulator covering thermocouple was tenth part of the gas channel width and many thermocouples were installed in the cell, resulting that the interference of thermocouples on mass, temperature and current density distributions was inevitable. Reference [9] also measured temperature distributions by the micro temperature sensor with a sensing area of $400 \mu \mathrm{m} \times 400 \mu \mathrm{m}$. Since this sensor was embedded in the cathode flow channel of separator, the temperature near the reaction surface was not measured.

In another study conducted by Nishimura, et al. [10], the temperature distributions on separator's back of single cell of PEFC were measured by thermograph. Without disturbing heat and mass transfer due to installation of sensor, the temperature distribution under power-generation conditions could be measured accurately. Based on the measuring data, the study tried to build an empirical model to predict the temperature distribution on reaction surface. According to literature survey by the study, there was no previous study on estimating the temperature distribution on reaction surface from measured temperature data at separator's back. If the heat-transfer model to predict the temperature distribution on reaction surface with the measured separator back's temperature would be developed, the temperature distribution on reaction surface could be easily estimated without difficult and complex temperature measurement.

In previous studies conducted by Nishimura, et al. $[11,12]$, in order to estimate the temperature distribution inside single cell of PEFC, an 1D multi-plate heat-transfer model using the temperature data of separator's back measured by thermograph under power-generation was developed. Since the single cell of PEFC consists of some components having plate shapes such as PEM, catalyst layer, GDL and separator, the previous studies by the authors [11, 12] proposed the heat-transfer model assuming the heat-transfer through multi-plates for these components of the cell. The reaction surface temperature $\left(T_{\text {react }}\right)$ was calculated using the heat-transfer model. This is a new approach to identify the heat-transfer mechanism in single cell of PEFC by means of the data measured by the thermograph and the model developed.

Comparing the results from the model with the other heat-transfer models proposed in previous studies [13-15], there are differences among them, e.g., heat source. Ref. [13] developed a simplified 1D model, which considered for the heat-transfer from PEM, catalyst layer, anode/cathode diffusion media and backing plate, based on Fourier's thermal conduction equation. This particular model [13] considered various heat sources such as Joule heating from PEM, entropic loss, activation and concentration overpotential, and Joule heating in catalyst layer. According to Ref. [13], the difference between $T_{\text {react }}$ and the backing plate (= separator) temperature was approximately $4.5{ }^{\circ} \mathrm{C}$ when the current density was $1.0 \mathrm{~A} / \mathrm{cm}^{2}$ and the backing plate end temperature was $80{ }^{\circ} \mathrm{C}$. Ref. [14] proposed another 1D model, which considered the heat-transfer among MEA (membrane electrode assembly), catalyst layer, GDL, and carbon current collector by investigating various types of Nafion PEMs such as NER-212, Nafion 112, Nafion 115, and Nafion 117. In the model [14], the heat-transfer through the in-plane direction of the cell was neglected and that toward the through-plane direction was investigated based on Fourier's thermal conduction equation. In addition, mole enthalpy of anode and cathode supply gas, vaporization enthalpy of water and reaction enthalpy were considered [14]. The difference between $T_{\text {react }}$ and the separator's back temperature was about $4{ }^{\circ} \mathrm{C}$ under the condition that MEA temperature was $85^{\circ} \mathrm{C}$. Ref. [15] developed a nonisothermal 2D model 
that considered the heat-transfer among PEM, catalyst layer, and GDL, in which thermal conduction through the cell components was considered. Additionally, heat capacitance and heat generation/depletion parameters, including thermodynamic irreversibility, heat generation by exothermic reaction, electron and proton transport resistance, and the phase change of water, were considered for Nafion PEMs. According to Ref. [15], the difference between $T_{\text {react }}$ and the temperature of current collector contacting the GDL at the cell voltage of $0.40 \mathrm{~V}$ was approximately $4{ }^{\circ} \mathrm{C}$ when using Nafion 115. Although there were differences in terms of heat-transfer calculations between the model developed by the present study and the other heat-transfer models proposed in previous studies [13-15], the temperature gradients for the targeted regions under the similar operation conditions were almost the same [11]. Thus, it can be believed that, the heat-transfer model proposed in the present study is reasonable.

The present paper focuses on comparing the temperature distribution calculated by 1D multi-plate heat-transfer model with that calculated by the other model considering the complex coupling phenomena in a cell of PEFC. If the result calculated by 1D multi-plate heat-transfer model agreed well with that from the model considering the compound effect such as fluid dynamics, gas diffusion, electrochemical reaction and heat-transfer in PEFC, it could conclude the simple 1D model which could be used to predict the coupling phenomena in PEFC.

The aim of the present paper is to prove that, the temperature distribution on the reaction surface calculated by 1D multi-plate heat-transfer model agrees with that by the numerical simulation using 3D model. For the numerical simulation, this study adopts the commercial CFD (computational fluid dynamics) software CFD-ACE+ (ESI Japan) which solves many governing equations on the coupling phenomena in a cell of PEFC such as fluid dynamics, gas diffusion, electrochemical reaction and heat-transfer at the same time. The effects of initial operation temperature, flow rate, and relative humidity of supply gas on temperature distribution on the reaction surface are investigated by the 1D model as well as the 3D model. The temperature distributions calculated by the 1D model and the 3D model are also compared with those reported by the precious studies.

\section{Calculation Procedure of Temperature Distribution}

\subsection{D Multi-plate Heat-Transfer Model}

Fig. 1 illustrates the multi-plate single cell PEFC module used in this study. In the module, the separator back is the opposite side of surface contacting GDL. The separator's back surface temperatures $T_{\text {surf, c }}$ and $T_{\text {surf, a }}$ were measured using thermograph. In the present study, the authors used the single cell consisting of separator and current collector in the power generation experiment in order to obtain the temperature and power-generation data for modeling heat-transfer phenomena in the cell because the precious studies which were referred by the present study used separator as component of single cell, not bipolar plate.

The heat-transfer across the module is assumed to be 1D multi-layer heat-transfer. In the module, the cell is divided into a gas channel part and a rib part. In Fig. 1, the upper and lower parts represent rib part and channel part, respectively. For both parts, the heat-transfer was assumed to be in the through-plane direction. It is assumed that, the thermal convection occurs on the surfaces of gas channel contacting GDL and the opposite surface. The reaction heat generated on the reaction surface is transferred to the cathode and anode sides separately. Although the gas flowing through the gas channel from the inlet to the outlet of the cell carries away some heat, the amount of heat taken is less than $1 \%$ of the estimated reaction heat which is approximately $20 \mathrm{~W}$ [11]. Therefore, the heat carried away by the gas flowing through the gas channel is neglected in this model. 
Anode separator back

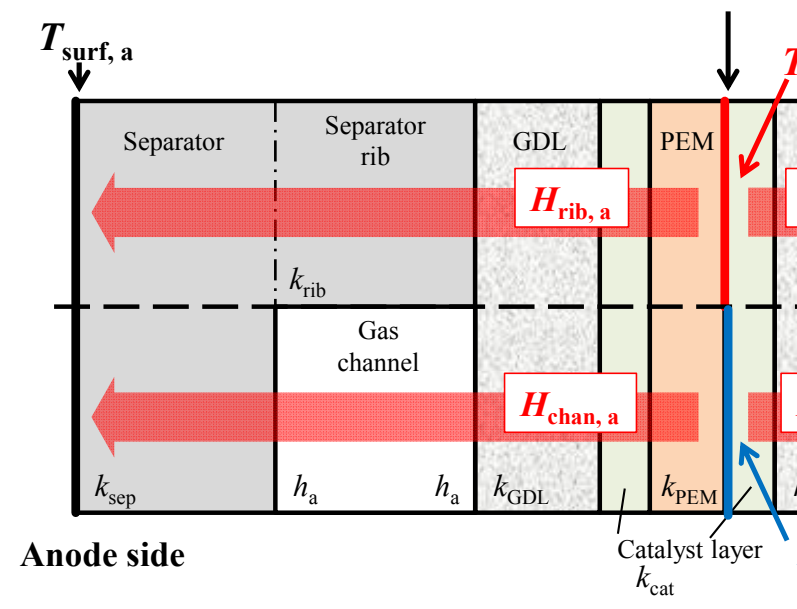

Cathode separator back

Fig. 1 Multi-plate module.

\subsection{Calculation of Heat Generation Rate by Reaction}

Heat generation rate $H_{\text {react }}$ as a reaction product is calculated as the following:

$$
H_{\text {react }}=E_{\mathrm{i}}-W_{\mathrm{E}}
$$

where, $E_{\mathrm{i}}$ is the ideal (total) energy generation rate by the water formation from $\mathrm{H}_{2}$ and $\mathrm{O}_{2}$ based on higher heating value; $W_{\mathrm{E}}$ is the electric work generated by PEFC. $E_{\mathrm{i}}$ and $W_{\mathrm{E}}$ are expressed as follows:

$$
\begin{gathered}
E_{\mathrm{i}}=m_{\mathrm{H} 2} \times q_{\mathrm{HHV}} \\
W_{\mathrm{E}}=I \times V
\end{gathered}
$$

where, $m_{\mathrm{H} 2}$ is the molar flow rate of supplied $\mathrm{H}_{2} ; q_{\mathrm{HHV}}$ is the higher heating value of $\mathrm{H}_{2}\left(=285.83 \times 10^{3} \mathrm{~J} \cdot \mathrm{mol}^{-1}\right)$; $I$ is the load current obtained by the experiment (=20 A); $V$ is the voltage obtained by the experiment. $m_{\mathrm{H} 2}$ is equal to the ideal reaction consumption rate of $\mathrm{H}_{2}$ required for the generation at $20 \mathrm{~A}$, i.e., the stoichiometric ratio of 1.0. The flow rate of the supply gas $\left(\mathrm{H}_{2}\right)$ at the stoichiometric ratio of 1.0 is defined from Eq. (4):

$$
m_{\mathrm{H} 2}=I / n F
$$

where, $n$ is the valence of ion $\left(=2\right.$ for $\left.\mathrm{H}_{2}\right) ; F$ is the Faraday constant $\left(=96,500 \mathrm{C} \cdot \mathrm{mol}^{-1}\right) \cdot m_{\mathrm{O} 2}$ which is the molar flow rate of supplied $\mathrm{O}_{2}$ is calculated by Eq. (5):

$$
\mathrm{H}_{2}+1 / 2 \mathrm{O}_{2}=\mathrm{H}_{2} \mathrm{O}
$$

The actual stoichiometric ratio of supply gas was confirmed, using the mass flow controller installed at the inlet of the single cell and the mass flow mater installed at the outlet of the cell in the power-generation experiment [10].

\subsection{Heat-Balance Equations for Calculating Temperature of Reaction Surface}

The heats transferred in the model proposed are expressed as Eqs. (6)-(10):

$$
\begin{gathered}
H_{\text {rib, c }}=K_{\text {rib, } \mathrm{c}} A\left(T_{\text {react, rib }}-T_{\text {surf, c }}\right) / 2 \\
H_{\text {chan, c }}=K_{\text {chan, } \mathrm{c}} A\left(T_{\text {react, chan }}-T_{\text {surf, c }}\right) / 2 \\
H_{\text {rib, a }}=K_{\text {rib, a }} A\left(T_{\text {react, rib }}-T_{\text {surf, a }}\right) / 2 \\
H_{\text {chan, a }}=K_{\text {chan, a }} A\left(T_{\text {react, chan }}-T_{\text {surf, a }}\right) / 2 \\
H_{\text {react }}=H_{\text {rib, c }}+H_{\text {chan, c }}+H_{\text {rib, a }}+H_{\text {chan, a }}
\end{gathered}
$$

where, $H_{\text {rib, c }}$ is the heat flux to cathode side under rib; $K_{\text {rib, c }}$ is the overall heat-transfer coefficient for cathode side under rib; $A$ is the heat-transfer area which is the active area of MEA, i.e., power-generation area $\left(=0.0025 \mathrm{~m}^{2}\right) ; T_{\text {react, rib is }}$ ise reaction surface temperature under rib; $T_{\text {surf, c }}$ is the cathode separator back temperature; $H_{\text {chan, } \mathrm{c}}$ is the heat flux to cathode side under channel; $K_{\text {chan, c }}$ is the overall heat-transfer coefficient for cathode side under channel; $T_{\text {react, chan }}$ is the reaction surface temperature under channel; $H_{\text {rib, a }}$ is the heat flux to anode side under rib; $K_{\text {rib, a }}$ is the overall heat-transfer coefficient 
for anode side under rib; $T_{\text {surf, a }}$ is the anode separator back temperature; $H_{\text {chan, a }}$ is the heat flux to anode side under channel; $K_{\text {chan, a }}$ is the overall heat-transfer coefficient for anode side under channel. $K_{\text {rib, c }}, K_{\text {chan, c }}$, $K_{\text {rib, a }}$ and $K_{\text {chan, a }}$ are defined as follows:

$$
\begin{gathered}
1 / K_{\mathrm{rib}, \mathrm{c}}=\delta_{\mathrm{cat}} / k_{\mathrm{cat}}+\delta_{\mathrm{GDL}} / k_{\mathrm{GDL}}+\delta_{\mathrm{rib}} / k_{\mathrm{rib}}+\delta_{\mathrm{sep}} / k_{\mathrm{sep}} \\
1 / K_{\mathrm{chan}, \mathrm{c}}=\delta_{\mathrm{cat}} / k_{\mathrm{cat}}+\delta_{\mathrm{GDL}} / k_{\mathrm{GDL}}+2 / h_{\mathrm{c}}+\delta_{\mathrm{sep}} / k_{\mathrm{sep}} \\
1 / K_{\mathrm{rib}, \mathrm{a}}=\delta_{\mathrm{PEM}} / k_{\mathrm{PEM}}+\delta_{\mathrm{cat}} / k_{\mathrm{cat}}+\delta_{\mathrm{GDL}} / k_{\mathrm{GDL}}+ \\
\delta_{\mathrm{rib}} / k_{\mathrm{rib}}+\delta_{\mathrm{sep}} / k_{\mathrm{sep}} \\
1 / K_{\mathrm{chan}, \mathrm{a}}=\delta_{\mathrm{PEM}} / k_{\mathrm{PEM}}+\delta_{\mathrm{cat}} / k_{\mathrm{cat}}+\delta_{\mathrm{GDL}} / k_{\mathrm{GDL}}+ \\
2 / h_{\mathrm{a}}+\delta_{\mathrm{sep}} / k_{\mathrm{sep}}
\end{gathered}
$$

where, $\delta_{\text {cat }}$ is the thickness of the catalyst layer; $k_{\text {cat }}$ is the thermal conductivity of the catalyst layer; $\delta_{\mathrm{GDL}}$ is the thickness of GDL; $k_{\mathrm{GDL}}$ is the thermal conductivity of GDL; $\delta_{\text {rib }}$ is the thickness of the separator rib; $k_{\text {rib }}$ is the thermal conductivity of the separator rib; $\delta_{\text {sep }}$ is the thickness of the separator excluding rib part; $k_{\text {sep }}$ is the thermal conductivity of the separator excluding rib part; $h_{\mathrm{c}}$ is the convection heat-transfer coefficient for cathode side; $\delta_{\mathrm{PEM}}$ is the thickness of PEM; $k_{\mathrm{PEM}}$ is the thermal conductivity of PEM; $h_{\mathrm{a}}$ is the convection heat-transfer coefficient for anode side.

Table 1 lists the specification of cell components used in the model. The materials of PEM, catalyst layer, GDL and separator are Nafion 115, compound of platinum and carbon, carbon paper and carbon graphite, respectively. The thickness values listed here are the same as those of the components used by previous studies [10, 16, 17].

In Table 1, the effective thermal conductivities of porous media $(k)$, are the values of the cell components used in the present experiment and in Refs. $[10,13]$. Because the effective thermal conductivities given in Table 1 are obtained when the cell component pores are filled with air at room temperature, the corrected effective thermal conductivities are calculated for the cell component pores filled with $\mathrm{H}_{2}$, or $\mathrm{O}_{2}$ at $70{ }^{\circ} \mathrm{C}$ or $80^{\circ} \mathrm{C}$. Tables 2 and 3 list the corrected effective thermal conductivities of each cell component at $70{ }^{\circ} \mathrm{C}$ and $80{ }^{\circ} \mathrm{C}$, respectively. In this calculation, the thermal conductivities of each gas are from the Japan Society of Mechanical Engineers [18].

The convective heat-transfer coefficient $h$ between the gas flows in the gas channel and GDL or separator wall is obtained from the study on heat-transfer in rectangular micro-channels [19]. The mass flow rates of the consumed gas and generated water in the gas channel, and the physical properties of the mixture gas were used for calculating the $R e$ and $h$. The relationship among the $\mathrm{Nu}$, aspect ratio of gas channel and Knudsen number for some $R e$ values has been reported [19]. Although the $R e$ is changed along the gas channel from the inlet to the outlet as well as with operation conditions, the $R e$ was assumed to be 10 under all operation conditions investigated in this study. The Nu was also assumed to be a constant due to the similarity of gas flow under the operation conditions investigated. The $\mathrm{Nu}$ was taken as 3.0 in the present study [19]. Convective heat-transfer

\begin{tabular}{|c|c|c|c|c|}
\hline Parts & Size & Characteristics & Porosity & $\begin{array}{l}\text { Effective thermal } \\
\text { conductivity } \\
\left(\mathrm{W} \cdot \mathrm{m}^{-1} \cdot \mathrm{K}^{-1}\right)\end{array}$ \\
\hline PEM & $50.0 \mathrm{~mm} \times 50.0 \mathrm{~mm} \times 0.13 \mathrm{~mm}$ & Nafion 115 (produced by Du Pont Corp.) & 0.15 & 0.195 \\
\hline Catalyst layer & $\begin{array}{l}50.0 \mathrm{~mm} \times 50.0 \mathrm{~mm} \times 0.01 \mathrm{~mm} \\
\text { (attached with PEM) }\end{array}$ & Pt/C (20 wt.\% Pt loading) & 0.78 & 0.27 \\
\hline GDL & $50.0 \mathrm{~mm} \times 50.0 \mathrm{~mm} \times 0.17 \mathrm{~mm}$ & $\begin{array}{l}\text { Carbon paper } \\
\text { (TGP-H-060 produced by Toray Corp.) }\end{array}$ & 0.78 & 1.7 \\
\hline Separator & $\begin{array}{l}75.4 \mathrm{~mm} \times 75.4 \mathrm{~mm} \times 2.00 \mathrm{~mm} \\
\text { (thickness of rib part: } 1.00 \mathrm{~mm} \text { ) } \\
\text { (gas supply area: } 50.0 \mathrm{~mm} \times 50.0 \mathrm{~mm} \text { ) }\end{array}$ & Carbon graphite, serpentine & 0.28 & 25 \\
\hline
\end{tabular}
coefficient $h$ is then calculated by Eq. (15):

$$
h=\mathrm{Nu} k_{\mathrm{chan}} / D_{\mathrm{h}}
$$

where, $k_{\text {chan }}$ is the effective thermal conductivity of

Table 1 Specification of cell components. 
Table 2 Corrected effective thermal conductivity of each cell component at $70^{\circ} \mathrm{C}$.

\begin{tabular}{lll}
\hline \multirow{2}{*}{ Component } & \multicolumn{2}{c}{$\begin{array}{c}\text { Effective thermal conductivity } \\
\left(\mathrm{W} \cdot \mathrm{m}^{-1} \cdot \mathrm{K}^{-1}\right)\end{array}$} \\
\cline { 2 - 3 } & Anode $\left(\mathrm{H}_{2}\right)$ & Cathode $\left(\mathrm{O}_{2}\right)$ \\
\hline PEM & 0.26 & - \\
Catalyst layer & 0.42 & 0.27 \\
GDL & 1.9 & 1.7 \\
Separator & 25 & 25 \\
\hline
\end{tabular}

Table 3 Corrected effective thermal conductivity of each cell component at $80^{\circ} \mathrm{C}$.

\begin{tabular}{lll}
\hline \multirow{2}{*}{ Component } & \multicolumn{2}{c}{$\begin{array}{c}\text { Effective thermal conductivity } \\
\left(\mathrm{W} \cdot \mathrm{m}^{-1} \cdot \mathrm{K}^{-1}\right)\end{array}$} \\
\cline { 2 - 3 } & Anode $\left(\mathrm{H}_{2}\right)$ & Cathode $\left(\mathrm{O}_{2}\right)$ \\
\hline PEM & 0.26 & - \\
Catalyst layer & 0.43 & 0.27 \\
GDL & 1.9 & 1.7 \\
Separator & 25 & 25 \\
\hline
\end{tabular}

mixture gas in channel; $D_{\mathrm{h}}$ is the hydraulic diameter of channel. In this study, the separator whose gas channel width and depth are $1.0 \mathrm{~mm}$ adopted, resulting that $D_{\mathrm{h}}$ is $1.0 \mathrm{~mm}$.

To solve Eqs. (6)-(9), the temperatures measured using the thermograph were substituted into these equations as $T_{\text {surf, c }}$ and $T_{\text {surf, a. The operation }}$ conditions used for power-generation in order to measure temperatures with thermograph are given in Table 4. Analysis using 1D multi-plate heat-transfer model as well as 3D numerical simulation model is carried out by means of the data obtained under these conditions. The experimental procedure for measuring temperature during power-generation has been explained in Ref. [10].

In order to use the temperature data measured by thermograph in 1D multi-plate heat-transfer model, the image of in-plane temperature distribution is divided into segments of $10 \mathrm{~mm} \times 10 \mathrm{~mm}$ each, as shown in Fig. 2. Although the power-generation area is $50 \mathrm{~mm} \times 50 \mathrm{~mm}$, the observation area is set to be $40 \mathrm{~mm} \times 50 \mathrm{~mm}$ to prevent gas leak through observation window in experiment. Space resolution and temperature resolution of the measurement by thermograph were $1.2 \mathrm{~mm}$ and $0.1{ }^{\circ} \mathrm{C}$, respectively. The gas channel width and the rib width of
Table 4 Operation conditions of power-generation for temperature measurement by thermograph.

\begin{tabular}{|c|c|c|}
\hline Initial temperature of cell $\left({ }^{\circ} \mathrm{C}\right)$ & 70,80 & \\
\hline $\begin{array}{l}\text { Load current of cell (A) } \\
\left.\text { (Current density of cell }\left(\mathrm{A} / \mathrm{cm}^{2}\right)\right)\end{array}$ & $\begin{array}{l}20 \\
(0.80)\end{array}$ & \\
\hline \multicolumn{3}{|l|}{ Supply gas condition } \\
\hline & Anode & Cathode \\
\hline $\begin{array}{l}\text { Temperature of supply gas at inlet } \\
\left({ }^{\circ} \mathrm{C}\right)\end{array}$ & 70,80 & 70,80 \\
\hline $\begin{array}{l}\text { Relative humidity of supply gas } \\
\text { (\% RH (relative humidity)) }\end{array}$ & 40,80 & 40,80 \\
\hline $\begin{array}{l}\text { Pressure of supply gas at inlet } \\
\text { (absolute) (MPa) }\end{array}$ & 0.4 & 0.4 \\
\hline $\begin{array}{l}\text { Flow rate of supply gas at inlet } \\
\text { (NL/min) (stoichiometric ratio) }\end{array}$ & $\begin{array}{l}0.210(1.5) \\
0.280(2.0) \\
0.420(3.0)\end{array}$ & $\begin{array}{l}0.105(1.5) \\
0.140(2.0) \\
0.210(3.0)\end{array}$ \\
\hline
\end{tabular}

investigated separator are $1.0 \mathrm{~mm}$ and the number of gas channel is 5 . The segment includes the area consisting of five pairs of rib and gas channel. The average temperature in each segment at anode and cathode was used for the separator's back temperature in 1D multi-plate heat-transfer model. The segment is named $\mathrm{A}$ to $\mathrm{T}$ along the gas-flow direction as shown in Fig. 2. Regarding segments $A$ and $\mathrm{T}$, the insulators covering the gas pipes interfere with the thermograph measurement in some area of the segment as it can be seen in Fig. 2. In this study, the effective temperature of segments $\mathrm{A}$ and $\mathrm{T}$ were obtained by removing the temperature data that were interfered by the insulator from the total temperature data in each segment. In the heat-transfer analysis, it was assumed that, $T_{\text {surf, c }}$ on the rib side was equal to $T_{\text {surf, c }}$ on the channel side as well as $T_{\text {surf, a }}$ because the difference between them could not be recognized by the measured data.

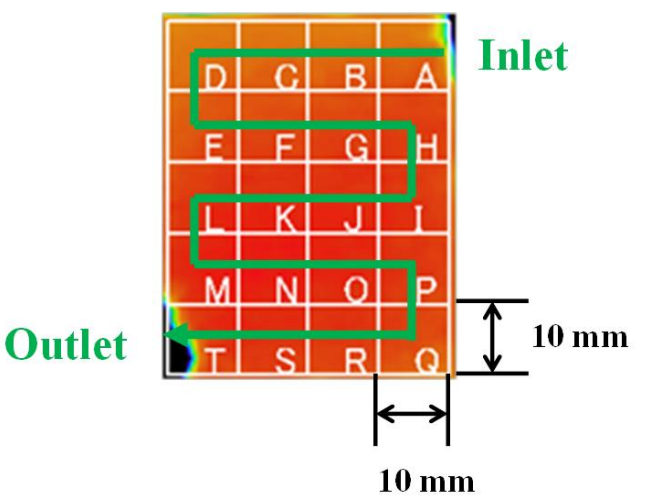

Fig. 2 Segment display of in-plane temperature distribution measured by thermograph. 
By the comparison of temperature distribution between in-plane and through-plane, the difference

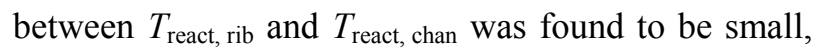
i.e., less than $1{ }^{\circ} \mathrm{C}[14,15,20]$, while the temperature difference between the reaction surface and separator's back was approximately $1-8{ }^{\circ} \mathrm{C}$ in the present study. Consequently, it is believed that, the heat flow in the through-plane direction dominates the heat-transfer in the cell.

Considering the above-described assumptions and Eqs. (6)-(14), the reaction surface temperature $T_{\text {react }}$ is expressed as follows:

$$
\begin{gathered}
T_{\text {react }}=T_{\text {react, rib }}=T_{\text {react, chan }} \\
=\left\{2 H_{\text {react }} / A+\left(K_{\text {rib, c }}+K_{\text {chan, c }}\right) / T_{\text {surf, c }}+\left(K_{\text {rib, a }}+\right.\right. \\
\left.K_{\text {chan, a })}\right) T_{\text {surf, a }\}} /\left(K_{\text {rib, c }}+K_{\text {chan, c }}+K_{\text {rib, a }}+K_{\text {chan, a }}\right)(16)
\end{gathered}
$$

\section{$2.43 D$ Numerical Simulation Model and Calculation}

\section{Conditions}

To verify the temperature distribution on the reaction surface calculated by $1 \mathrm{D}$ multi-plate heat-transfer model, the numerical simulation using 3D model was conducted by CFD-ACE+. This CFD software has the simulation code for PEFC composed of the equations such as conservation equations of mass, momentum and energy in porous region as well as electrochemical reaction explained by the previous research in detail [21]. Although the detailed explanation for all equations concedes Ref. [21], the conservation equation for energy is written as [22, 23]:

$$
\begin{gathered}
\partial\left\{(1-\varepsilon) \rho_{\mathrm{s}} h_{\mathrm{s}}+\varepsilon \rho h\right\} / \partial t+\nabla \cdot(\varepsilon \rho U h) \\
=\nabla \cdot q+\varepsilon \tau \nabla U+\varepsilon(\mathrm{d} p / \mathrm{d} t)-I_{\mathrm{T}} \eta+|i \cdot i| / \sigma+S_{h}
\end{gathered}
$$

where, $\varepsilon$ is porosity; $\rho_{\mathrm{s}}$ is mass density of solid; $h_{\mathrm{s}}$ is enthalpy of solid; $\rho$ is mass density of mixture; $h$ is enthalpy of mixture; $t$ is lapse time; $U$ is fluid velocity vector; $q$ is heat flux; $\tau$ is shear stress tensor; $p$ is absolute pressure; $I_{\mathrm{T}}$ is net transfer current due to electrochemical reaction; $\eta$ is electrode overpotential; $i$ is net current density; $\sigma$ is electrical conductivity; $S_{h}$ is enthalpy source due to phase change. The heat flux $q$ is comprised of thermal conduction and species diffusion, and is written as [24]:

$$
q=\lambda \nabla T+\sum_{i=1}^{N_{G}} J_{i} h_{i}
$$

where, $\lambda$ is effective thermal conductivity; $T$ is bulk temperature; $N_{\mathrm{G}}$ is total number of gas species; $J_{i}$ is diffusion flux of $i$-th species; $h_{i}$ is enthalpy of $i$-th species. The effective thermal conductivity of the fluid and solid region is written as [25]:

$$
\lambda=-2 \lambda_{\mathrm{S}}+1 /\left\{\varepsilon /\left(2 \lambda_{\mathrm{S}}+\lambda_{\mathrm{F}}\right)+(1-\varepsilon) / 3 \lambda_{\mathrm{S}}\right\}
$$

where, $\lambda_{\mathrm{S}}$ is thermal conductivity of solid in porous region; $\lambda_{\mathrm{F}}$ is thermal conductivity of fluid (or pore) in porous region. Consideration on conservation of enthalpy, heat derived from shear stress and pressure drop of fluid flow, and heat derived from current transfer is the different point in 3D numerical simulation model compared to the 1D multi-plate heat-transfer model.

To solve the conservation equation was performed by using a finite volume scheme on arbitrary mesh topology within the framework of the commercial CFD code CFD-ACE+. The governing equations are derived on the basis of the following assumptions [26, 27]:

(1) The volume of condensed water is ignored and the water moves with gas;

(2) The reduction of the reaction area caused by flooding in electrode is ignored and diffusion prevention caused by water condensation is ignored;

(3) Cell voltage is uniform and constant;

(4) The effective porosity and the permeability of porous media are isotropic;

(5) Heat-transfer between gas and solid phase of porous media is ignored;

(6) Fluid is incompressible Newtonian fluid and ideal gas. Flow condition is a laminar flow;

(7) The distribution of inlet gas flow rate at each side is uniform;

(8) In PEM, ionic conductivity, electro-osmosis coefficient, and water effective diffusion coefficient that depend on humidity are disregarded; 
(9) The gas cross over through PEM is disregarded.

The validation of simulation procedure using these equations has been already proved well [26-30].

Fig. 3 and Table 5 show the simulation model and the calculation conditions other than the conditions shown earlier in Table 4, respectively.

As shown in Fig. 3, the model width corresponds to a pair of gas channel and rib, which is the length from the rib center to the next rib center. The structure was assumed to be symmetric about the rib in order to clarify two questions regarding the temperature gradients: (1) How large the through-plane (Y axis direction in Fig. 3) temperature difference between the reaction surface and separator's back at cathode is? (2) How large the in-plane ( $Z$ axis direction in Fig. 3) temperature distribution between the gas channel center and the rib center on the reaction surface is? By the $3 \mathrm{D}$ numerical simulation, the temperature difference between reaction surface and separator's back was clarified, resulting that the heat-transfer in $\mathrm{Y}$ axis direction was investigated. In addition, the temperature distribution in $\mathrm{Z}$ axis direction on the reaction surface was also investigated by the $3 \mathrm{D}$ numerical simulation. The 1D multi-plate heat-transfer model was verified by the $3 \mathrm{D}$ model through these investigations. The thicknesses of cell components are given in Table 1. The temperature data measured by thermograph during power-generation experiment were used as the boundary condition for the separator's back temperature at anode and cathode. This boundary condition was the same as the one used in 1D multi-plate heat-transfer model. As shown in Fig. 3, the counter flow was simulated for gas flow in gas channel of separator, which was followed by the power-generation experiment in the previous study [10].

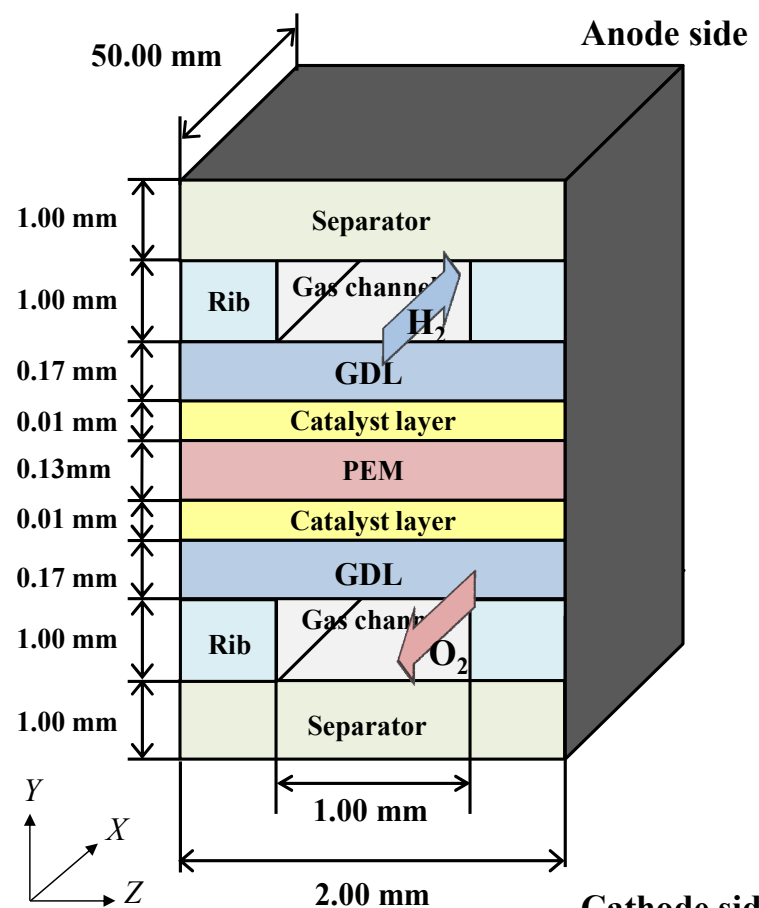

Fig. 3 3D model for numerical simulation by CFD-ACE+.

Table 5 Calculation conditions (A: for porous media; B: for solid media).

\begin{tabular}{llll}
\hline A & GDL & Catalyst layer & PEM \\
\hline Porosity & 0.78 & 0.78 & 0.28 \\
Permeability (through-plane) $\left(\mathrm{m}^{2}\right)$ & $8.69 \times 10^{-12}$ & $8.69 \times 10^{-12}$ & $1.0 \times 10^{-18}$ \\
Permeability (in-plane) $\left(\mathrm{m}^{2}\right)$ & $1.6 \times 10^{-11}$ & $1.6 \times 10^{-11}$ & $1.0 \times 10^{-6}$ \\
Mean particle size $(\mathrm{m})$ & $1.0 \times 10^{-6}$ & $1.0 \times 10^{-6}$ & - \\
Effective catalyst area $\left(1 \cdot \mathrm{m}^{-1}\right)$ & - & 1,000 & 0.195 \\
Thermal conductivity (through-plane) $\left(\mathrm{W} \cdot \mathrm{m}^{-1} \cdot \mathrm{K}^{-1}\right)$ & 1.7 & 0.27 & $1.0 \times 10^{-20}$ \\
Thermal conductivity (in-plane) $\left(\mathrm{W} \cdot \mathrm{m}^{-1} \cdot \mathrm{K}^{-1}\right)$ & 22 & 53 & \\
Electric conductivity (isotropy) $\left(1 \cdot \mathrm{ohm}^{-1} \cdot \mathrm{m}^{-1}\right)$ & 53 & & \\
\hline B & & Separator \\
\hline & 1,720 & \\
\hline Density $\left(\mathrm{kg} \cdot \mathrm{m}^{-3}\right)$ & $8.3 \times 10^{4}$ \\
Electric conductivity $\left(1 \cdot \mathrm{ohm}^{-1} \cdot \mathrm{m}^{-1}\right)$ & 810 & \\
Specific heat $\left(\mathrm{J} \cdot \mathrm{kg}^{-1} \cdot \mathrm{K}^{-1}\right)$ & 25 & \\
Thermal conductivity $\left(\mathrm{W} \cdot \mathrm{m}^{-1} \cdot \mathrm{K}^{-1}\right)$ & & \\
\hline
\end{tabular}


The gas channel length (to $\mathrm{X}$ axis direction in Fig. 3) was set at $50 \mathrm{~mm}$ which was equal to the one straight path length of the actual separator used for power-generation experiment [10]. Though this length is short compared to the actual total length of separator from the inlet to the outlet, this model assumes the part near the inlet. If wider mass and temperature distributions were occurred near the inlet under the simulation conditions, it would be thought that, the factor causing the distribution influences more strongly for the whole cell. In addition, the main purpose of this study is to verify the temperature distribution on the reaction surface calculated by 1D multi-plate heat-transfer model. Since the initial conditions such as flow rate and temperature of supply gas can be set at the same values accurately for both 1D multi-plate heat-transfer model and 3D numerical simulation model, this 3D model meets the purpose of this study as the first step. It is planned the study will be extended to cover the computational domain to $\mathrm{X}$ axis direction as well in the near future.

To investigate the impact of operation condition on mass and temperature distributions, $T_{\text {ini }}$, flow rate and relative humidity of supply gas were varied. Furthermore, the temperature distribution on the reaction surface calculated by the numerical simulation using 3D model was compared to that calculated by 1D multi-plate heat-transfer model as well as the results reported by the previous studies.

\section{Results and Discussion}

\subsection{Temperature Distribution Calculated by $1 D$ Multi-plate Heat-Transfer Model}

Fig. 4 shows the effect of $T_{\text {ini }}$ on temperature distribution on reaction surface calculated by 1D multi-plate heat-transfer model in each segment in cell at $T_{\text {ini }}$ of $70{ }^{\circ} \mathrm{C}$ and $80{ }^{\circ} \mathrm{C}$, respectively. The stoichiometric ratio of supply gases are 1.5, 2.0 and 3.0. The relative humidity of supply gas is $80 \% \mathrm{RH}$.

It can be seen from Fig. 4 that, the reaction surface temperature rise from $T_{\text {ini }}$, i.e., $T_{\text {react }}-T_{\text {ini, }}$, at $T_{\text {ini }}$ of $70{ }^{\circ} \mathrm{C}$ is higher than that at $T_{\text {ini }}$ of $80{ }^{\circ} \mathrm{C}$ irrespective of flow rate of supply gas. The reason was thought to be that $\mathrm{O}_{2}$ was used as the cathode gas and was sufficient even if the stoichiometric ratio of the supply gas was 1.5 .

According to the voltages obtained by power-generation experiments as listed in Table 6, the voltages at $T_{\text {ini }}$ of $70{ }^{\circ} \mathrm{C}$ are lower than those at $T_{\text {ini }}$ of $80{ }^{\circ} \mathrm{C}$ irrespective of flow rate of supply gas. At

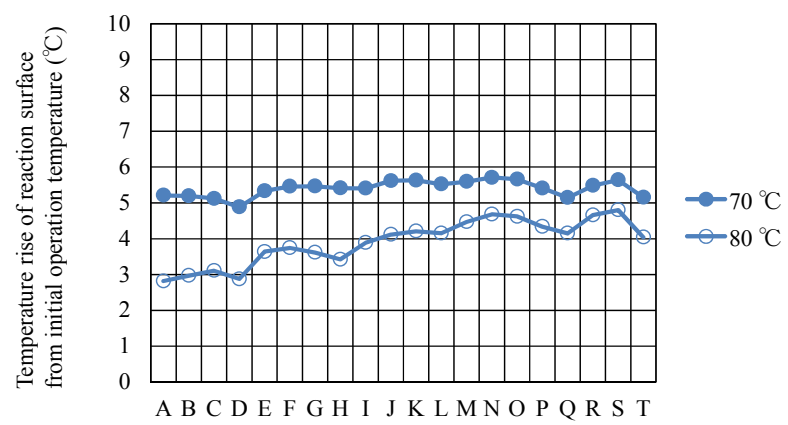

(a)

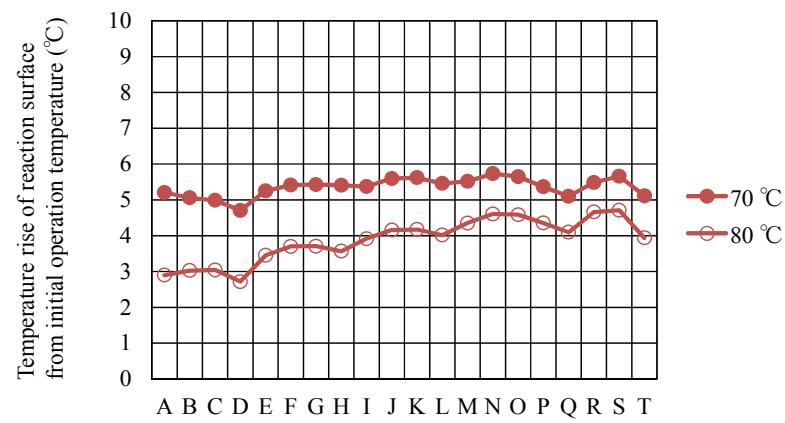

(b)

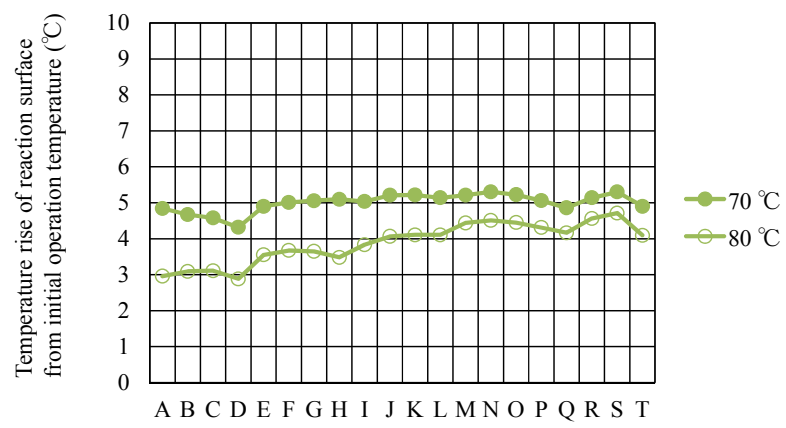

(c)

Fig. 4 Effect of initial operation temperature on temperature distribution on reaction surface calculated by 1D multi-plate heat-transfer model: (a) stoichiometric ratio of 1.5 ; (b) stoichiometric ratio of 2.0 ; (c) stoichiometric ratio of 3.0. 
Table 6 Comparison of voltage obtained by power-generation experiment among different operation conditions.

\begin{tabular}{llll}
\hline Initial operation temperature $\left({ }^{\circ} \mathrm{C}\right)$ & 70 & 80 \\
\hline $\begin{array}{l}\text { Relative humidity of supply gas } \\
(\% \mathrm{RH})\end{array}$ & 80 & 40 & 80 \\
\hline Flow rate of supply gas & & & \\
\hline Stoichiometric ratio: 1.5 & $0.52 \mathrm{~V}$ & $0.40 \mathrm{~V}$ & $0.54 \mathrm{~V}$ \\
Stoichiometric ratio: 2.0 & $0.52 \mathrm{~V}$ & $0.37 \mathrm{~V}$ & $0.53 \mathrm{~V}$ \\
Stoichiometric ratio: 3.0 & $0.52 \mathrm{~V}$ & $0.34 \mathrm{~V}$ & $0.53 \mathrm{~V}$ \\
\hline
\end{tabular}

higher $T_{\text {ini, }}$, the kinetics for both electrode reactions are enhanced [31]. Therefore, it is thought that, the power-generation performance of PEFC is promoted at higher $T_{\text {ini }}$. When the $W_{\mathrm{E}}$ at $T_{\text {ini }}$ of $70{ }^{\circ} \mathrm{C}$ is lower than that at $T_{\text {ini }}$ of $80^{\circ} \mathrm{C}, H_{\text {react }}$ at $T_{\text {ini }}$ of $70^{\circ} \mathrm{C}$ is higher than that at $T_{\text {ini }}$ of $80^{\circ} \mathrm{C}$ as derived from Eqs. (1) and (3). Consequently, $T_{\text {react }}$ at $T_{\text {ini }}$ of $70{ }^{\circ} \mathrm{C}$ is higher than that at $T_{\text {ini }}$ of $80^{\circ} \mathrm{C}$.

In addition, it can be seen from Fig. 4 that $T_{\text {react }}-$ $T_{\text {ini }}$ drops in the segments of $\mathrm{D}, \mathrm{H}, \mathrm{Q}$ and $\mathrm{T}$. This is because, water droplets are easy to resident at the turn-round parts of gas channel and the outlet in the case of serpentine gas channel [32-34] used in the present experiment and the previous study [10]. The gas diffusion toward catalyst layer is disturbed in these segments, resulting that the electrochemical reaction is not carried out well. Thus, $T_{\text {react }}$ drops in these segments. Therefore, it is important to remove the water from the turn-round parts of gas channel in order to achieve the even in-plane temperature distribution on reaction surface.

Fig. 5 shows the effect of relative humidity of supply gas on temperature distribution on reaction surface calculated by 1D multi-plate heat-transfer model, when the stoichiometric ratio of supply gases are 1.5, 2.0 and 3.0. $T_{\text {ini }}$ is $70{ }^{\circ} \mathrm{C}$.

It can be seen from Fig. 5 that, the $T_{\text {react }}-T_{\text {ini }}$ for $40 \% \mathrm{RH}$ is higher than that for $80 \% \mathrm{RH}$ irrespective of flow rate of supply gas. According to the experimental results, the voltage generated with $40 \%$ $\mathrm{RH}$ is smaller than that with $80 \% \mathrm{RH}$ as shown in Table 6. Since the PEM conductivity decreases with decrease in water content in PEM [35], the membrane resistance increases. Therefore, the voltage drops with decrease in the relative humidity of supply gas. As derived from Eqs. (1) and (3), $H_{\text {react }}$ for $40 \% \mathrm{RH}$ is higher than that for $80 \% \mathrm{RH}$. Consequently, $T_{\text {react }}$ for $40 \% \mathrm{RH}$ is higher than that for $80 \% \mathrm{RH}$.

In addition, it is known from Fig. 5 that, the increase in $T_{\text {react }}-T_{\text {ini }}$ along gas flow direction for $40 \% \mathrm{RH}$ is larger compared to that for $80 \% \mathrm{RH}$. When the relative humidity of supply gas is $80 \% \mathrm{RH}$, the electrochemical reaction is conducted well from the inlet of cell throughout the cell due to the sufficient humidification of PEM. The water produced by electrochemical reaction is accumulated along the gas flow direction through gas channel, resulting that

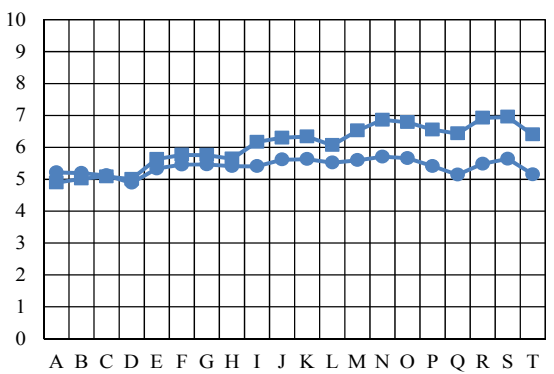

$-80 \% \mathrm{RH}$ $-40 \% \mathrm{RH}$

(a)

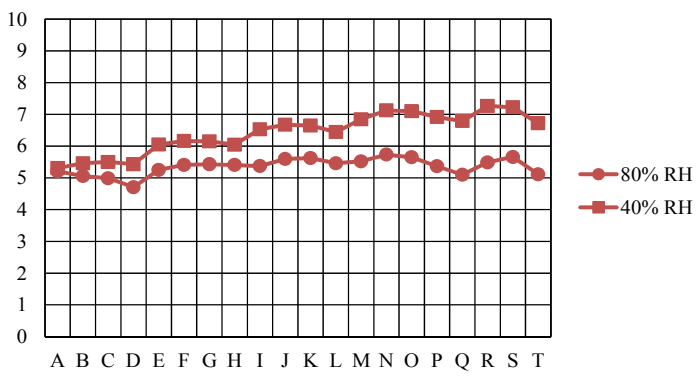

(b)

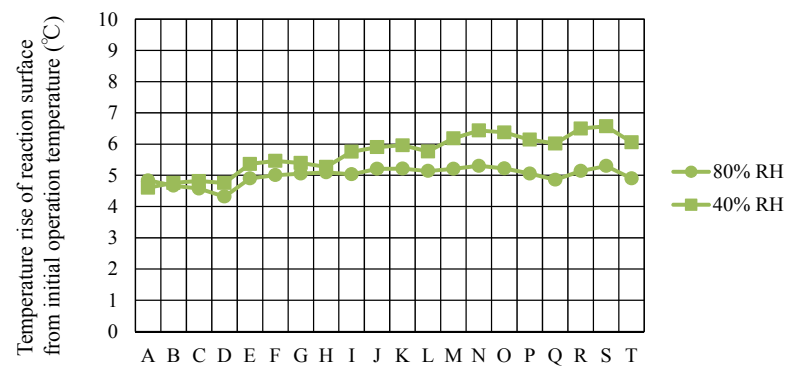

(c)

Fig. 5 Effect of relative humidity of supply gas on temperature distribution on reaction surface calculated by 1D multi-plate heat-transfer model: (a) stoichiometric ratio of 1.5; (b) stoichiometric ratio of 2.0 ; (c) stoichiometric ratio of 3.0. 
the gas diffusion inhibition by accumulated water might be occurred toward the outlet of cell. Therefore, the $T_{\text {react }}-T_{\text {ini }}$ near the outlet does not increase so much. On the other hand, when the relative humidity of supply gas is $40 \% \mathrm{RH}$, the humidification of PEM is not good especially near the inlet of cell. However, the water produced by electrochemical reaction humidifies PEM gradually from the segments A to $\mathrm{T}$ without gas diffusion inhibition since the excess water does not exist. Therefore, the electrochemical reaction is conducted well through gas channel, resulting in the increase in $T_{\text {react }}-T_{\text {ini }}$ along gas flow direction. However, the total power-generation performance with $40 \% \mathrm{RH}$ is worse than that with $80 \% \mathrm{RH}$ due to the larger membrane resistance even if the electrochemical reaction is conducted better for $40 \%$ $\mathrm{RH}$ along the gas flow direction in the gas channel.

The total power-generation performance with $80 \%$ $\mathrm{RH}$ is better than that with $40 \% \mathrm{RH}$ according to Table 6 and the in-plane temperature distribution for $80 \% \mathrm{RH}$ is more even than that for $40 \% \mathrm{RH}$ according to Fig. 5. It can then conclude that, the higher power-generation performance is obtained under the condition leading even in-plane temperature distribution on the reaction surface.

\subsection{Mass and Temperature Distribution Calculated by} Numerical Simulation Using 3D Model

The characteristics of in-plane mass and temperature distributions in $\mathrm{Z}$ axis direction are found to be similar among the investigated conditions. The results obtained under the condition that $T_{\text {ini }}$ is $70{ }^{\circ} \mathrm{C}$ and the relative humidity of supply gas is $80 \% \mathrm{RH}$ are shown below.

Fig. 6 shows the molar concentration distribution of $\mathrm{H}_{2}$ in $\mathrm{Z}$ axis direction on the interface between PEM and catalyst layer at anode where the anode electrochemical reaction occurs. Since the molar concentration distribution of $\mathrm{H}_{2}$ in $\mathrm{Z}$ axis direction does not change along the gas channel in $\mathrm{X}$ axis direction, the molar concentration distribution of $\mathrm{H}_{2}$ at

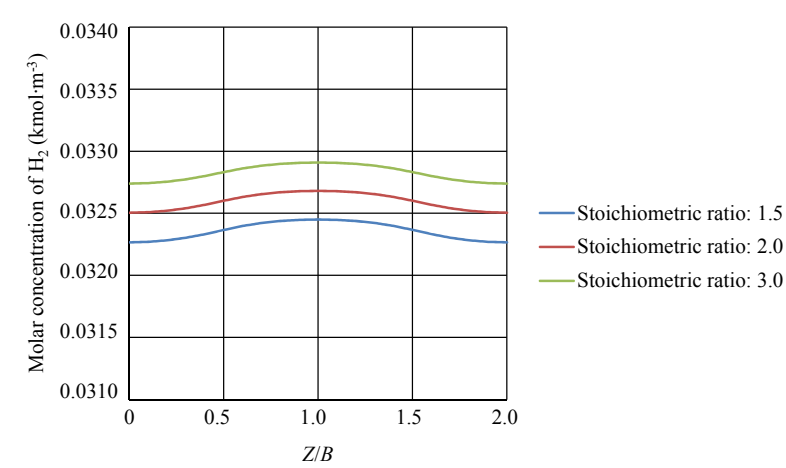

Fig. 6 Molar concentration distribution of $\mathrm{H}_{2}$ on interface between PEM and catalyst layer at anode calculated by numerical simulation using 3D model $\left(T_{\text {ini }}: 70^{\circ} \mathrm{C}\right.$; relative humidity of supply gas: $80 \% \mathrm{RH}$ ).

$X=25 \mathrm{~mm}$ which is the gas channel center in $X$ axis direction is given in Fig. 6. In Fig. 6, $B$ means the gas channel pitch of separator, which is $1.0 \mathrm{~mm}$. The range from $Z / B=0.5-1.5$ indicates the interface between PEM and catalyst layer at anode under the gas channel, while the range from $Z / B=0-0.5$ and that from $Z / B=1.5-2.0$ indicate the interface between PEM and catalyst layer at anode under the rib.

From Fig. 6, it is clear that, the molar concentration of $\mathrm{H}_{2}$ under the gas channel is higher than that under the rib. In addition, the highest and the lowest peaks of molar concentration of $\mathrm{H}_{2}$ are observed at the gas channel center and the rib center, respectively. The gas passing through gas channel diffuses toward through-plane direction and in-plane direction in cell via GDL to catalyst layer. Since there is a large molar concentration difference of $\mathrm{H}_{2}$ between the gas channel and the rib at the interface between separator and GDL, the molar concentration of $\mathrm{H}_{2}$ under the gas channel is higher than that under the rib on the interface between PEM and catalyst layer at anode. Furthermore, it is seen that, the amount of molar concentration of $\mathrm{H}_{2}$ increases with increase in flow rate of supply gas. Since the amount of gas in gas channel increases and the gas diffusion rate is enhanced with increase in flow rate of supply gas, the amount of molar concentration of $\mathrm{H}_{2}$ on the interface between PEM and catalyst layer at anode increases. 
Fig. 7 shows the molar concentration distribution of $\mathrm{O}_{2}$ in $\mathrm{Z}$ axis direction on the reaction surface where the cathode electrochemical reaction occurs. Since the molar concentration distribution of $\mathrm{O}_{2}$ in $\mathrm{Z}$ axis direction does not change along the gas channel in $\mathrm{X}$ axis direction, the molar concentration distribution of $\mathrm{O}_{2}$ at $\mathrm{X}=25 \mathrm{~mm}$ is given in Fig. 7 .

From Fig. 7, it is clear that, the molar concentration of $\mathrm{O}_{2}$ under the gas channel is higher than that under the rib. In addition, the highest and the lowest peaks of molar concentration of $\mathrm{O}_{2}$ are observed at the gas channel center and the rib center, respectively. As same as the discussion for Fig. 6, there is a large molar concentration difference of $\mathrm{O}_{2}$ between the gas channel and the rib at the interface between separator and GDL, the molar concentration of $\mathrm{O}_{2}$ under the gas channel is higher than that under the rib on the reaction surface. Moreover, it is seen that, the amount of molar concentration of $\mathrm{O}_{2}$ increases with increase in flow rate of supply gas. As same as the discussion for Fig. 6, the amount of molar concentration of $\mathrm{O}_{2}$ on the reaction surface increases since the amount of gas in gas channel increases and the gas diffusion rate is enhanced with increase in flow rate of supply gas.

Fig. 8 shows the molar concentration distribution of water in $\mathrm{Z}$ axis direction on the reaction surface where the cathode electrochemical reaction occurs. Since the molar concentration distribution of water in $\mathrm{Z}$ axis direction does not change along the gas channel in $\mathrm{X}$ axis direction, the molar concentration distribution of water at $\mathrm{X}=25 \mathrm{~mm}$ is given in Fig. 8 .

From Fig. 8, it is clear that, the molar concentration of water under the rib is higher than that under the gas channel. In addition, the highest and the lowest peaks of molar concentration of water are observed at the rib center and the gas channel center, respectively. These tendencies are opposed to the molar concentration distribution of $\mathrm{O}_{2}$ as well as that of $\mathrm{H}_{2}$. It is thought that, the water under the gas channel is easy to be discharged by $\mathrm{O}_{2}$ passing toward the outlet of cell. Therefore, the molar concentration of water on the

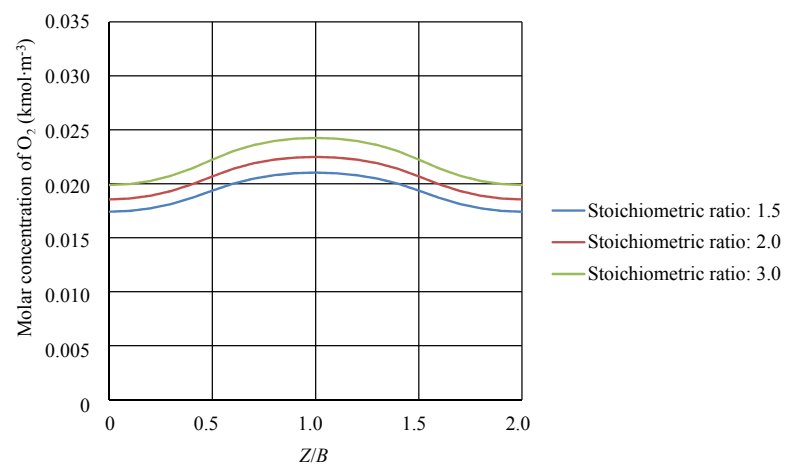

Fig. 7 Molar concentration distribution of $\mathrm{O}_{2}$ on reaction surface calculated by numerical simulation using 3D model $\left(T_{\text {ini: }}: 7^{\circ} \mathrm{C}\right.$; relative humidity of supply gas: $\left.80 \% \mathrm{RH}\right)$.

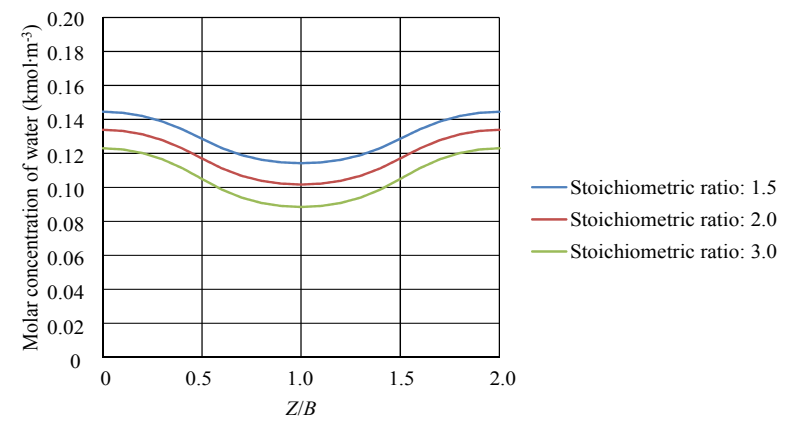

Fig. 8 Molar concentration distribution of water on reaction surface calculated by numerical simulation using 3D model ( $T_{\text {ini }}: 70{ }^{\circ} \mathrm{C}$; relative humidity of supply gas: $80 \%$ RH).

reaction surface under the gas channel is lower compared to that under the rib. Furthermore, the amount of molar concentration of water decreases with increase in flow rate of supply gas. As described above, since the water under gas channel is discharged by $\mathrm{O}_{2}$ passing toward the outlet, the amount of discharged water is larger with increase in flow rate of supply gas. Consequently, the amount of molar concentration of water on the reaction surface decreases with increase in flow rate of supply gas.

Fig. 9 shows the temperature distribution on reaction surface in $\mathrm{Z}$ axis direction which is evaluated by $T_{\text {react }}-T_{\text {ini }}$. Since the $T_{\text {react }}$ distribution in $\mathrm{Z}$ axis direction does not change along the gas channel in $\mathrm{X}$ axis direction, the temperature distribution at $\mathrm{X}=25$ $\mathrm{mm}$ is given in Fig. 9.

From Fig. 9, it is clear that, the $T_{\text {react }}-T_{\text {ini }}$ under the rib is higher than that under the gas channel. In 

Heat-Transfer Model and a 3D Numerical Simulation Model

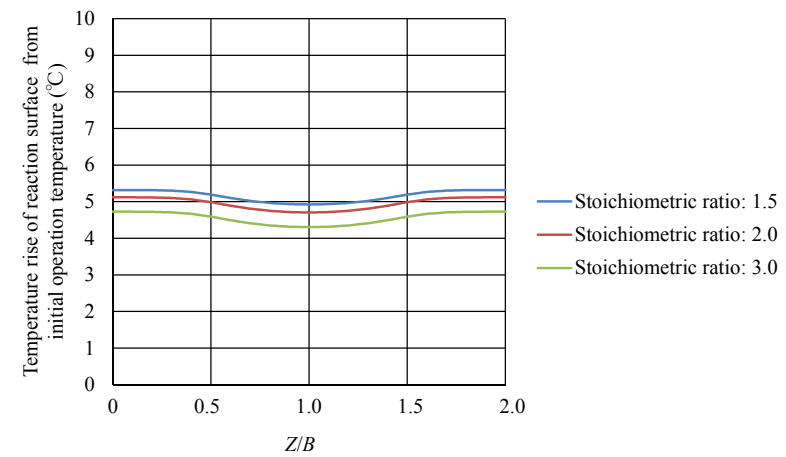

Fig. 9 Temperature distribution on reaction surface calculated by numerical simulation using $3 \mathrm{D}$ model $\left(T_{\text {ini }}\right.$ : $70{ }^{\circ} \mathrm{C}$; relative humidity of supply gas: $\left.80 \% \mathrm{RH}\right)$.

addition, the highest and the lowest peaks of $T_{\text {react }}-$ $T_{\text {ini }}$ are observed at the rib center and the gas channel center, respectively. Since the amount of $\mathrm{O}_{2}$ under the gas channel is larger compared to that under the rib, it is thought that, the convection heat-transfer by $\mathrm{O}_{2}$ passing toward the outlet of cell is larger. Therefore, the $T_{\text {react }}-T_{\text {ini }}$ under the gas channel becomes lower than that under the rib. Moreover, $T_{\text {react }}-T_{\text {ini }}$ decreases with increase in flow rate of supply gas. The convection heat-transfer by $\mathrm{O}_{2}$ passing toward the outlet is larger with increase in flow rate of supply gas, resulting in the decrease in $T_{\text {react }}-T_{\text {ini. }}$. Although the temperature difference between $T_{\text {react }}-T_{\text {ini }}$ under the gas channel and that under the rib as well as mass distributions in $\mathrm{Z}$ axis direction are confirmed by the numerical simulation using $3 \mathrm{D}$ model, the temperature difference is below $1{ }^{\circ} \mathrm{C}$, which is the similar level to the precious studies $[14,15,20]$. Consequently, it is thought that, the assumption of 1D multi-plate heat-transfer model regarding $T_{\text {react }}$, i.e., $T_{\text {react, rib }}=$

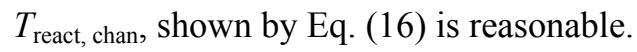

To investigate the effect of $T_{\text {ini }}$ on temperature distribution on reaction surface in $\mathrm{Z}$ axis direction which is calculated by the numerical simulation using 3D model, Fig. 10 shows the temperature distributions evaluated by $T_{\text {react }}-T_{\text {ini }}$ at $\mathrm{X}=25 \mathrm{~mm}$ at $T_{\text {ini }}$ of $70^{\circ} \mathrm{C}$ and $80{ }^{\circ} \mathrm{C}$, respectively. The temperature distributions at $T_{\text {ini }}$ of $70{ }^{\circ} \mathrm{C}$ and $80{ }^{\circ} \mathrm{C}$ with the relative humidity of supply gas of $80 \% \mathrm{RH}$ are compared under the same flow rate of supply gas.

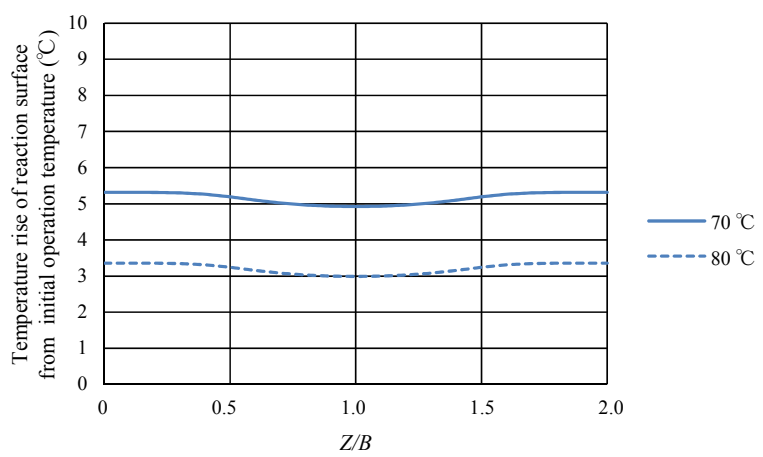

(a)

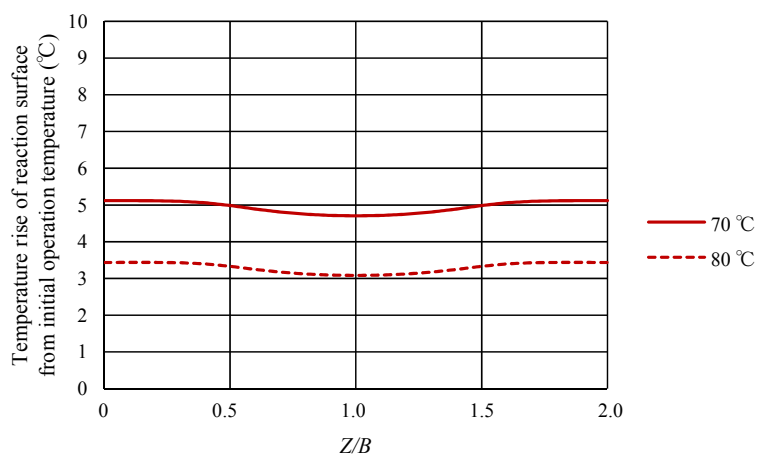

(b)

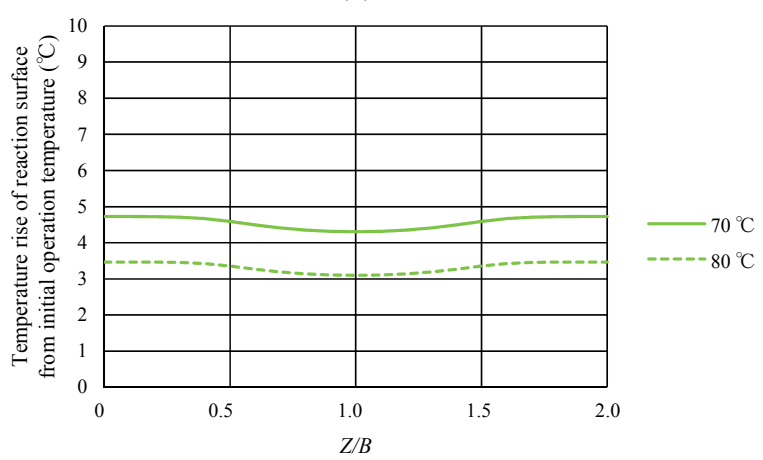

(c)

Fig. 10 Effect of initial operation temperature on temperature distribution on reaction surface calculated by numerical simulation using 3D model: (a) stoichiometric ratio of 1.5; (b) stoichiometric ratio of 2.0 ; (c) stoichiometric ratio of 3.0.

According to Fig. 10, it is known that, the $T_{\text {react }}-$ $T_{\text {ini }}$ at $T_{\text {ini }}$ of $70{ }^{\circ} \mathrm{C}$ is higher than that at $T_{\text {ini }}$ of $80^{\circ} \mathrm{C}$ by approximately $1.5-2.0^{\circ} \mathrm{C}$. Compared to the results obtained by 1D multi-plate heat-transfer model shown in Fig. 4, the temperature difference between $T_{\text {ini }}$ of $70{ }^{\circ} \mathrm{C}$ and $80^{\circ} \mathrm{C}$ in the segments $\mathrm{B}$ and $\mathrm{C}$ is almost the same, where the position of $\mathrm{X}=25 \mathrm{~mm}$ corresponds to the interface between the segments $\mathrm{B}$ and $\mathrm{C}$. Consequently, the same finding is obtained by both 

Heat-Transfer Model and a 3D Numerical Simulation Model

1D multi-plate heat-transfer model and the numerical simulation using 3D model.

To investigate the effect of relative humidity of supply gas on temperature distribution on reaction surface in $\mathrm{Z}$ axis direction which is calculated by the numerical simulation using 3D model, Fig. 11 shows the temperature distributions evaluated by $T_{\text {react }}-T_{\text {ini }}$ at $\mathrm{X}=25 \mathrm{~mm}$ at $T_{\text {ini }}$ of $70{ }^{\circ} \mathrm{C}$ with relative humidity of supply gas of $80 \% \mathrm{RH}$ and $40 \% \mathrm{RH}$, respectively. The

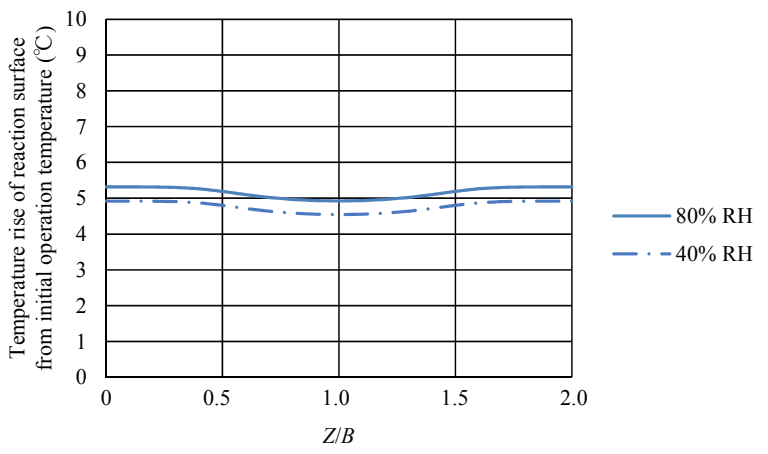

(a)

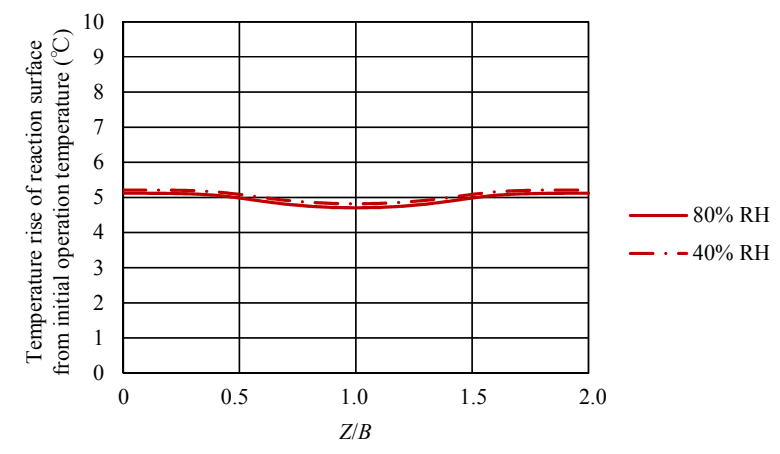

(b)

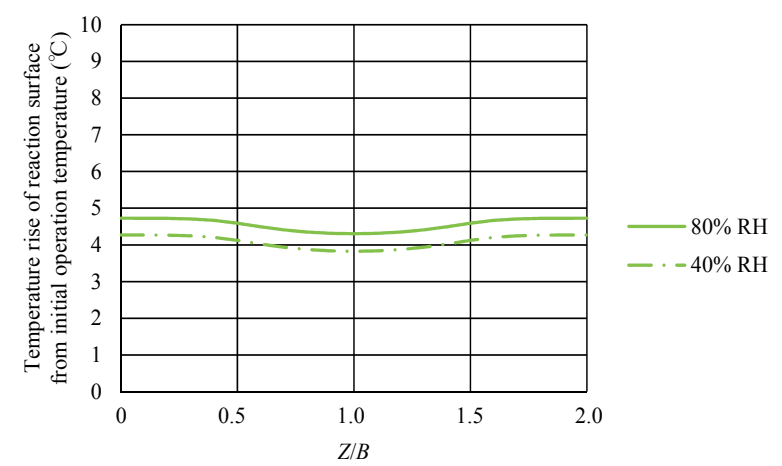

(c)

Fig. 11 Effect of relative humidity of supply gas on temperature distribution on reaction surface calculated by numerical simulation using 3D model: (a) stoichiometric ratio of 1.5; (b) stoichiometric ratio of 2.0; (c) stoichiometric ratio of 3.0. temperature distributions with $80 \% \mathrm{RH}$ and $40 \% \mathrm{RH}$ are compared under the same flow rate of supply gas.

According to Fig. 11, it is known that, the $T_{\text {react }}-$ $T_{\text {ini }}$ for $40 \% \mathrm{RH}$ is almost the same as that for $80 \%$ $\mathrm{RH}$ irrespective of flow rate of supply gas. As shown in Fig. 5, the temperature difference between $40 \% \mathrm{RH}$ and $80 \% \mathrm{RH}$ in the segments $\mathrm{B}$ and $\mathrm{C}$ obtained by $1 \mathrm{D}$ multi-plate heat-transfer model is very small. It is believed that, the effect of relative humidity of supply gas on temperature distribution on reaction surface is little, which is led by $1 \mathrm{D}$ multi-plate heat-transfer model as well as the numerical simulation using 3D model. Since the impact of water produced by electrochemical reaction on gas diffusion and heat-transfer near the inlet of cell is a little compared to the outlet, the effect of relative humidity of supply gas on temperature distribution on reaction surface calculated by the numerical simulation using 3D model might not be found in this study. As the near future plan, this study will extend the computational domain to $\mathrm{X}$ axis direction in order to consider the effect of water accumulation on temperature distribution.

3.3 Comparison of Temperature Distribution on Reaction Surface between the $1 D$ Multi-plate Heat-Transfer Model and the 3D Numerical Simulation Model

Tables 7,8 and 9 list $T_{\text {react }}-T_{\text {ini }}$ in the segments $\mathrm{A}$, B, C and D under the condition that $T_{\text {ini }}$ is $70{ }^{\circ} \mathrm{C}$ and the relative humidity of supply gas is $80 \% \mathrm{RH}, T_{\text {ini }}$ is $80{ }^{\circ} \mathrm{C}$ and the relative humidity of supply gas is $80 \%$ $\mathrm{RH}$, and $T_{\text {ini }}$ is $70{ }^{\circ} \mathrm{C}$ and the relative humidity of supply gas is $40 \% \mathrm{RH}$, respectively. $T_{\text {react }}$ averaged from $Z / B=0$ to 2.0 at each center position of $\mathrm{X}$ axis direction in the segments $\mathrm{A}, \mathrm{B}, \mathrm{C}$ and $\mathrm{D}$ is listed in these tables as the representative temperature obtained by the numerical simulation using 3D model.

According to Tables 7-9, the maximum differences of $T_{\text {react }}$ between 1D multi-plate heat-transfer model and $3 \mathrm{D}$ numerical simulation model are $0.4{ }^{\circ} \mathrm{C}(=8 \%)$, $0.3{ }^{\circ} \mathrm{C}(=10 \%)$ and $0.7{ }^{\circ} \mathrm{C}(=17 \%)$, respectively. 
Table 7 Comparison of temperature distribution on reaction surface between 1D multi-plate heat-transfer model and 3D numerical simulation model $\left(T_{\text {ini: }}: 7^{\circ} \mathrm{C}\right.$; relative humidity of supply gas: $\left.80 \% \mathrm{RH}\right)$.

\begin{tabular}{|c|c|c|c|c|c|c|}
\hline \multirow{2}{*}{$\begin{array}{l}\text { Initial operation } \\
\text { temperature, relative } \\
\text { humidity of supply gas }\end{array}$} & \multirow{2}{*}{$\begin{array}{l}\text { Stoichiometric } \\
\text { ratio }\end{array}$} & \multirow[t]{2}{*}{ Model } & \multicolumn{4}{|c|}{$\begin{array}{c}\text { Temperature rise of reaction surface from initial operation } \\
\text { temperature }\left({ }^{\circ} \mathrm{C}\right)\end{array}$} \\
\hline & & & Segment A & Segment B & Segment C & Segment D \\
\hline \multirow{6}{*}{$70{ }^{\circ} \mathrm{C}, 80 \% \mathrm{RH}$} & \multirow{2}{*}{1.5} & 1D multi-plate heat transfer & 5.4 & 5.3 & 5.3 & 5.0 \\
\hline & & 3D numerical simulation & 5.4 & 5.3 & 5.3 & 5.0 \\
\hline & \multirow{2}{*}{2.0} & 1D multi-plate heat transfer & 5.0 & 5.1 & 5.1 & 4.7 \\
\hline & & 3D numerical simulation & 5.4 & 5.2 & 5.1 & 4.9 \\
\hline & \multirow{2}{*}{3.0} & 1D multi-plate heat transfer & 4.7 & 4.7 & 4.7 & 4.4 \\
\hline & & 3D numerical simulation & 5.0 & 4.8 & 4.7 & 4.5 \\
\hline
\end{tabular}

Table 8 Comparison of temperature distribution on reaction surface between 1D multi-plate heat-transfer model and 3D numerical simulation model $\left(T_{\mathrm{ini}}: 80^{\circ} \mathrm{C}\right.$; relative humidity of supply gas: $\left.80 \% \mathrm{RH}\right)$.

\begin{tabular}{|c|c|c|c|c|c|c|}
\hline \multirow{2}{*}{$\begin{array}{l}\text { Initial operation } \\
\text { temperature, relative } \\
\text { humidity of supply gas }\end{array}$} & \multirow{2}{*}{$\begin{array}{l}\text { Stoichiometric } \\
\text { ratio }\end{array}$} & \multirow[t]{2}{*}{ Model } & \multicolumn{4}{|c|}{$\begin{array}{c}\text { Temperature rise of reaction surface from initial operation } \\
\text { temperature }\left({ }^{\circ} \mathrm{C}\right)\end{array}$} \\
\hline & & & Segment A & Segment B & Segment C & Segment D \\
\hline \multirow{6}{*}{$80{ }^{\circ} \mathrm{C}, 80 \% \mathrm{RH}$} & \multirow{2}{*}{1.5} & 1D multi-plate heat transfer & 3.2 & 3.3 & 3.4 & 3.0 \\
\hline & & 3D numerical simulation & 3.0 & 3.1 & 3.3 & 3.0 \\
\hline & \multirow{2}{*}{2.0} & 1D multi-plate heat transfer & 3.3 & 3.4 & 3.4 & 3.0 \\
\hline & & 3D numerical simulation & 3.0 & 3.2 & 3.2 & 2.9 \\
\hline & \multirow{2}{*}{3.0} & 1D multi-plate heat transfer & 3.3 & 3.5 & 3.5 & 3.2 \\
\hline & & 3D numerical simulation & 3.1 & 3.2 & 3.3 & 3.0 \\
\hline
\end{tabular}

Table 9 Comparison of temperature distribution on reaction surface between 1D multi-plate heat-transfer model and 3D numerical simulation model $\left(T_{\text {ini }}: 7^{\circ} \mathrm{C}\right.$; relative humidity of supply gas: $\left.40 \% \mathrm{RH}\right)$.

\begin{tabular}{|c|c|c|c|c|c|c|}
\hline \multirow{2}{*}{$\begin{array}{l}\text { Initial operation } \\
\text { temperature, relative } \\
\text { humidity of supply gas }\end{array}$} & \multirow{2}{*}{$\begin{array}{l}\text { Stoichiometric } \\
\text { ratio }\end{array}$} & \multirow{2}{*}{ Model } & \multicolumn{4}{|c|}{$\begin{array}{c}\text { Temperature of reaction surface from initial operation } \\
\text { temperature }\left({ }^{\circ} \mathrm{C}\right)\end{array}$} \\
\hline & & & Segment A & Segment B & Segment C & Segment D \\
\hline \multirow{6}{*}{$70{ }^{\circ} \mathrm{C}, 40 \% \mathrm{RH}$} & \multirow{2}{*}{1.5} & 1D multi-plate heat transfer & 4.7 & 4.9 & 4.9 & 4.6 \\
\hline & & 3D numerical simulation & 4.8 & 5.2 & 5.2 & 5.2 \\
\hline & \multirow{2}{*}{2.0} & 1D multi-plate heat transfer & 4.9 & 5.2 & 5.2 & 4.9 \\
\hline & & 3D numerical simulation & 5.4 & 5.6 & 5.7 & 5.5 \\
\hline & \multirow{2}{*}{3.0} & 1D multi-plate heat transfer & 4.0 & 4.2 & 4.3 & 4.1 \\
\hline & & 3D numerical simulation & 4.7 & 4.9 & 5.0 & 4.8 \\
\hline
\end{tabular}

Though the 1D multi-plate heat-transfer model proposed by this study treats the heat-transfer phenomena in the cell of PEFC simpler, the model can predict the temperature distribution on the reaction surface on equal terms with the 3D model solving many governing equations on the coupling phenomena in a cell of PEFC.

According to the previous 2D numerical simulation study, considering the heat generation and depletion by reversible/irreversible heat release, ohmic heating and phase change of water [36], $T_{\text {react }}-T_{\text {ini }}$ ranging from $1{ }^{\circ} \mathrm{C}$ to $6{ }^{\circ} \mathrm{C}$ was reported under the condition that $T_{\text {ini }}$ was $70{ }^{\circ} \mathrm{C}$, the relative humidity of supply gas was $100 \% \mathrm{RH}$, and the cell voltage ranged from $0.30 \mathrm{~V}$ to $0.70 \mathrm{~V}$. In addition, from the other 3D numerical simulation study accounting for various heat generation mechanisms including irreversible heat due to electrochemical reactions, entropic heat and Joule heating arising from the electrolyte ionic resistance [37], $T_{\text {react }}-T_{\text {ini }}$ ranging from $2{ }^{\circ} \mathrm{C}$ to $11{ }^{\circ} \mathrm{C}$ was reported under the condition that $T_{\text {ini }}$ was $70{ }^{\circ} \mathrm{C}$, the relative humidity of supply gas at anode was $75 \% \mathrm{RH}$, the relative humidity of supply gas at cathode was $0 \% \mathrm{RH}$, and the cell voltage was $0.6 \mathrm{~V}$. Moreover, according to the experimental study measuring the PEM temperature by temperature sensor [38], $T_{\text {react }}-T_{\text {ini }}$ 

Heat-Transfer Model and a 3D Numerical Simulation Model

ranging from $2{ }^{\circ} \mathrm{C}$ to $3{ }^{\circ} \mathrm{C}$ was reported under the condition that $T_{\text {ini }}$ was $80{ }^{\circ} \mathrm{C}$, the relative humidity of supply gas was $100 \% \mathrm{RH}$, and the cell voltage was $0.2 \mathrm{~V}$. Compared with the above previous studies conducted under the similar operation conditions [36-38], it is obvious that, $T_{\text {react }}-T_{\text {ini }}$ calculated by the $1 \mathrm{D}$ multi-plate heat-transfer model in this study as well as by the $3 \mathrm{D}$ model are correct. The temperature gradients from the reaction surface to the separator's back obtained by the $1 \mathrm{D}$ multi-plate heat-transfer model range approximately from $1{ }^{\circ} \mathrm{C}$ to $8^{\circ} \mathrm{C}$, while those obtained by the previous studies [13-15, 36-38] range approximately from $1{ }^{\circ} \mathrm{C}$ to $11{ }^{\circ} \mathrm{C}$. Consequently, the simple 1D multi-plate heat-transfer model proposed by this study is effective for prediction of temperature distribution on the reaction surface.

\section{Conclusions}

The temperature distribution on the reaction surface calculated by the 1D multi-plate heat-transfer model proposed has been validated by the numerical simulation using a $3 \mathrm{D}$ model as well as the previous studies. In addition, the effects of $T_{\text {ini }}$, flow rate and relative humidity of supply gas on the temperature distribution on the reaction surface have been also investigated by the $1 \mathrm{D}$ multi-plate heat-transfer model as well as the 3D numerical simulation model. From the investigation of this study, the following conclusions have been obtained:

(1) The $T_{\text {react }}-T_{\text {ini }}$ at $T_{\text {ini }}$ of $70{ }^{\circ} \mathrm{C}$ is higher than that at $T_{\text {ini }}$ of $80^{\circ} \mathrm{C}$ irrespective of flow rate of supply gas. Since the power-generation performance of PEFC is promoted at higher $T_{\text {ini }}, H_{\text {react }}$ at $T_{\text {ini }}$ of $70{ }^{\circ} \mathrm{C}$ is higher than that at $T_{\text {ini }}$ of $80^{\circ} \mathrm{C}$, which is derived from Eqs. (1) and (3);

(2) The $T_{\text {react }}-T_{\text {ini }}$ with $40 \% \mathrm{RH}$ is almost the same as that with $80 \% \mathrm{RH}$ near the inlet of the cell irrespective of flow rate of supply gas. However, the increase in $T_{\text {react }}-T_{\text {ini }}$ along gas flow from the segments $\mathrm{A}$ to $\mathrm{T}$ for $40 \% \mathrm{RH}$ is larger compared to
$80 \% \mathrm{RH}$ according to the 1D multi-plate heat-transfer model. It is because that, the impact of water produced by electrochemical reaction on gas diffusion and heat-transfer near the inlet of cell is smaller compared to the outlet;

(3) Although the 1D multi-plate heat-transfer model proposed by this study treats the heat-transfer phenomena in the cell of PEFC in a simple way, the model can predict the temperature distribution on the reaction surface on equal terms with the $3 \mathrm{D}$ model solving many governing equations on the coupling phenomena in a cell of PEFC;

(4) The $T_{\text {react }}-T_{\text {ini }}$ calculated by the $1 \mathrm{D}$ multi-plate heat-transfer model as well as the numerical simulation using 3D model agrees with that in previous studies conducted under the similar operation conditions;

(5) The simple 1D multi-plate heat-transfer model proposed by this study is effective for prediction of temperature distribution on the reaction surface.

\section{Acknowledgments}

This work was supported by Mie prefecture industrial research institute. The authors acknowledge its great contribution.

\section{References}

[1] Kubo, N., Fukuyama, Y., Mashio, T., Sakamoto, Y., Kusaka, J., and Daisho, Y. 2004. "Study on Transport Phenomena in Polymer Electrolyte Fuel Cell (First Report) - the Experimental and Numerical Investigation by the Use of Segmented Cell-." J. Soc. Automot. Eng. Japan Trans. 35 (4): 65-71.

[2] Weber, A. Z., Darling, R. M., and Newman, J. 2004. "Modeling Two-Phase Behavior in PEFCs." $J$. Electrochemical Society 151 (10): A1715-27.

[3] Wang, M., Guo, H., and Ma, C. 2006. "Temperature Distribution on the MEA Surface of a PEMFC with Serpentine Channel Flow Bed." J. Power Sources 157 (1): 181-7.

[4] Ito, K. 2008. "Temperature Distribution Measurement in Through-Plane Direction for PEFC." Japan Society of Mechanical Engineers 111 (1079): 42-4.

[5] Tsuji, K. 2008. "Domestic Fuel Cell Co-generation System Entering Real Commercial Stage.” Hydrogen 
Energy System 33 (3): 93-6.

[6] Uchida, H. 2008. "Observation on Polymer Electrolyte Fuel Cell for High Performance and High Durability and Priority Subject on Technology Development in Future." In Proceedings of the Analysis on Degradation Mechanism of Polymer Electrolyte Fuel Cell, Preprints of the NEDO Symposium, 35-41.

[7] Zhang, G., Shen, S., Guo, L., and Liu, H. 2012. "Dynamic Characteristics of Local Current Densities and Temperatures in Proton Exchange Membrane Fuel Cells during Reactant Starvations.” Int. J. Hydrogen Energy 37 (2): 1884-92.

[8] Zhang, G., Guo, L., Ma, L., and Liu, H. 2010. "Simultaneous Measurement of Current and Temperature Distributions in a Proton Exchange Membrane Fuel Cell." J. Power Sources 195 (11): 3597-604.

[9] Lee, C. Y., Fan, W. Y., and Chang, C. P. 2011. "A Novel Method for in-situ Monitoring of Local Voltage, Temperature and Humidity Distributions in Fuel Cell Using Flexible Multi-functional Micro Sensors." Sensors 11 (2): 1418-32.

[10] Nishimura, A., Shibuya, K., Morimoto, A., Tanaka, S., Hirota, M., Nakamura, Y., Kojima, M., Narita, M., and Hu, E. 2012. "Dominant Factor and Mechanism of Coupling Phenomena in Single Cell of Polymer Electrolyte Fuel Cell." Applied Energy 90 (1): 73-9.

[11] Nishimura, A., Iio, K., Baba, M., Yamauchi, T., Hirota, M., and Hu, E. 2014. "Modeling of Heat Transfer in Single Cell of Polymer Electrolyte Fuel Cell by Means of Temperature Data Measured by Thermograph." $J$. Chemical Engineering of Japan 47 (7): 521-9.

[12] Nishimura, A., Fukuoka, T., Baba, M., Hirota, M., and $\mathrm{Hu}$, E. "Clarification on Temperature Distribution in Single Cell of Polymer Electrolyte Fuel Cell under Different Operation Conditions by Means of 1D Multi-plate Heat-Transfer Model." J. Chemical Engineering of Japan (in press).

[13] Khandelwal, M., and Mench, M. M. 2006. "Direct Measurement of Through-Plane Thermal Conductivity and Contact Resistance in Fuel Cell Materials.” J. Power Sources 161 (2): 1106-15.

[14] Kawase, M., Inagaki, T., Kawashima, S., and Miura, K. 2009. "Effective Thermal Conductivity of Gas Diffusion Layer in Through-Plane Direction.” ECS Trans. 25 (1): 1529-37.

[15] Jung, C. Y., Shim, H. S., Koo, S. M., Lee, S. H., and Yi, S. C. 2012. "Investigation of the Temperature Distribution in Proton Exchange Membrane Fuel Cell." Applied Energy 93 (May): 733-41.

[16] Hwang, S. S., Han, S. S., Lee, P. H., and Park, B. I. 2010. "Transient Performance Behavior of Proton Exchange Membrane Fuel Cell by Configuration of Membrane and
Gas Diffusion Layer." J. Thermal Science and Technology 5 (1): 165-77.

[17] Wu, H., Berg, P., and Li, X. 2010. "Steady and Unsteady 3D Non-isothermal Modeling of PEM Fuel Cells with the Effect of Non-equilibrium Phase Transfer." Applied Energy 87 (9): 2778-84.

[18] The Japan Society of Mechanical Engineers. 1993. "JSME Heat Transfer Handbook." The Japan Society of Mechanical Engineers.

[19] Renksizbulut, M., Niazmand, H., and Tercan, G. 2006. "Slip-Flow and Heat Transfer in Rectangular Microchannels with Constant Wall Temperature." International J. Thermal Science 45 (9): 870-81.

[20] Oshima, A., Nishimura, A., Morimoto, A., Tanaka, S., Hirota, M., and Narita, M. 2010. "Theoretical Investigation on Influence of Inflow Gas Condition and Gas Channel Structure of Separator on Mass and Temperature Distribution in Single Cell of Polymer Electrolyte Fuel Cell." In Proceedings of the Mechanical Engineering Congress, 203-4.

[21] Nishimura, A., Morimoto, A., Tanaka, S., Oshima, A., Hirota, M., Tohma, E., Kimura, Y., and Narita, M. 2012. "Influence of Cell Components Structure on Heat and Mass Transfer Phenomena in Single-Cell PEFC." $J$. Energy and Power Engineering 6 (4): 504-18.

[22] Bird, R. B., Stewart, W. E., and Lightfoot, E. N. 1960. Transport Phenomena. Tokyo: Toppan Company Ltd., 81-2.

[23] Kaviany, M. 1999. Principles of Heat Transfer in Porous Media. New York: Springer, 145-8, 166-72.

[24] Gurau, V., Liu, H., and Kakac, S. 1998. Two-Dimensional Model for Proton Exchange Membrane Fuel Cells." AIChE J. 44 (11): 2410-22.

[25] Dagan, G. 1989. Flow and Transport in Porous Formations. Berlin: Splinger-Verlag Berlin Heidelberg, 55-61, 82-3, 89-91.

[26] Mazumdar, S., and Cole, J. V. 2003. "Rigorous 3-D Mathematical Modeling of PEM Fuel Cells, I. Model Predictions without Liquid Water Transport." $J$. Electrochemical Society 150 (11): A1503-9.

[27] Mazumdar, S., and Cole, J. V. 2003. "Rigorous 3-D Mathematical Modeling of PEM Fuel Cells, II. Model Predictions with liquid Water Transport." $J$. Electrochemical Society 150 (11): A1510-7.

[28] Senn, S. M., and Poulikakos, D. 2004. "Polymer Electrolyte Fuel Cells with Porous Materials as Fluid Distributors and Comparisons with Traditional Channeled Systems." J. Heat Transfer 126 (3): 410-8.

[29] Wang, Y., and Wang, C. Y. 2006. "A Nonisothermal Two-Phase Model for Polymer Electrolyte Fuel Cells." $J$. Electrochemical Society 153 (6): A1193-200.

[30] Wu, H., Berg, P., and Li, X. 2008. "Steady and Unsteady 
704 Temperature Distributions in Single Cell of Polymer Electrolyte Fuel Cell Simulated by an 1D Multi-plate Heat-Transfer Model and a 3D Numerical Simulation Model

3D Non-isothermal Modeling of PEM Fuel Cells with the Effect of Non-equilibrium Phase Transfer." In Proceedings of the 4th International Green Energy Conference, 200-11.

[31] Li, Q., He, R., Jensen, J. O., and Bjerrum, N. J. 2003. "Approaches and Recent Development of Polymer Electrolyte Membranes for Fuel Cells Operating above $100{ }^{\circ} \mathrm{C}$." Chemical Material 15 (26): 4896-915.

[32] Kramer, D., Zhang. J., Shimoi, R., Lehmann, E., Wokaun, A., Shinohara, K., and Sherer, G. G. 2005. "In situ Diagnostic of Two-Phase Flow Phenomena in Polymer Electrolyte Fuel Cells by Neutron Imaging, Part A. Experimental, Data Treatment, and Quantification." Electrochimical Acta 50 (13): 2603-14.

[33] Zhang, F. Y., Yang, X. G., and Wang, C. Y. 2006. "Liquid Water Removal from a Polymer Electrolyte Fuel Cell.” J. Elecrtrochemical Society 153 (2): A225-32.

[34] Zhang, J., Kramer, D., Shimoi, R., Ono, Y., Lehmann, E., Wokaun, A., Shinohara, K., and Sherer, G. G. 2006. "In situ Diagnostic of Two-Phase Flow Phenomena in Polymer Electrolyte Fuel Cells by Neutron Imaging, Part B. Material Variations." Electrochimical Acta 51 (13): 2715-27.

[35] Springer, T. E., Zawodzinski, T. A., and Gottersfeld, S. 1991. "Polymer Electrolyte Fuel Cell Model." J. Electrochemical Society 138 (8): 2334-42.

[36] Jung, C. Y., Shim, H. S., Koo, S. M., Lee, S. H., and Yi, S. C. 2012. "Investigation of the Temperature Distribution in Proton Exchange Membrane Fuel Cells." Applied Energy 93 (May): 733-41.

[37] Ju, H., Meng, H., and Wang, C. Y. 2005. "A Single-Phase, Non-isothermal Model for PEM Fuel Cells." International J. Heat and Mass Transfer 48 (7): 1303-15.

[38] He, S., Mench, M. M., and Tadigadapa, S. 2006. "Thin Film Temperature Sensor for Real-Time Measurement of Electrolyte Temperature in a Polymer Electrolyte Fuel Cell." Sensors and Actuators A 125 (2): 170-7. 